\title{
The Late Pleistocene Fossil Birds of the Central and Southern Ryukyu Islands, and their Zoogeographical Implications for the Recent Avifauna of the Archipelago
}

\author{
Hiroshige MATSUOKA Department of Geology and Mineralogy, Graduate School of Science, \\ Kyoto University. Kyoto, 606-8502 Japan
}

\begin{abstract}
Paleontological research for the Late Pleistocene (the last glacial maximum in general) fossil association of birds of the Central and Southern Ryukyu islands, which consists of forty-four species included in 17 families in 11 orders, revealed that the recent aspect of avian endemics, inhabiting one island only, is in fact due to relict palaeoendemism (i.e., they are remnant distributions, left over from the extirpations on other island / area populations). Also, the fossil distribution of Oriental birds indicates that the recent northern limit of the Oriental zoogeographical region, Hachisuka's line between the Southern and Central Ryukyus, is an "artificial" boundary that does not account for the vanished distributions. The forests of the Amamis and "Yambaru" in Okinawa are very important ecological habitats because they are, already, the result of local extinctions from the native one. We must take their present condition into consideration for the preservation of unique ecological habitats.
\end{abstract}

Key words: Late Pleistocene / avifauna / Ryukyu Islands / zoogeography / avian paleontology / extirpation

The fauna of the Ryukyu Archipelago, bridging between Kyushu in the north and Taiwan in the southwest, is of high zoogeographical interest. It includes many endemic species, and it is located on the boundary between the Oriental and Palaearctic zoogeographical regions.

Biogeographical investigations revealed that faunal distributions accorded with suggestions on the positions of the boundary between the Oriental and Palaearctic regions. By the middle of this century, it began to be accepted that the Watase's line, between the Amamis and Osumis, is the most important boundary for terrestrial animals (e.g., Kuroda, 1931). Also, the close relationship between the faunas of the Amamis and the Okinawas was pointed out, and for this reason the Central Ryukyus have frequently been treated as one unique "subregion".

Some taxa, however, exhibit distributional patterns that do not fit the expectations of Watase's line. Aves, the subject of this study, shows the most enigmatic pattern. Hachisuka (1926) considered that the Yaeyamas are the northern limit of distribution for Oriental birds, though Kuroda $(1925,1931)$ pointed out that Watase's line applies also to birds. Yamashina (1941) studied the Purple Jay (Lidth's Jay), Ryukyu Robin and Pryer's Woodpecker (Sapheopipo noguchii), which were once regarded as endemic genera and species (named Lalocitta lidthi and Icoturus komadori respectively for the former two). He considered that the three species are allied to Garrulus species, Erithacus akahige, and Dendrocops (=Picoides) or Picus, respectively. Further, he concluded that the Central Ryukyu Islands should be 


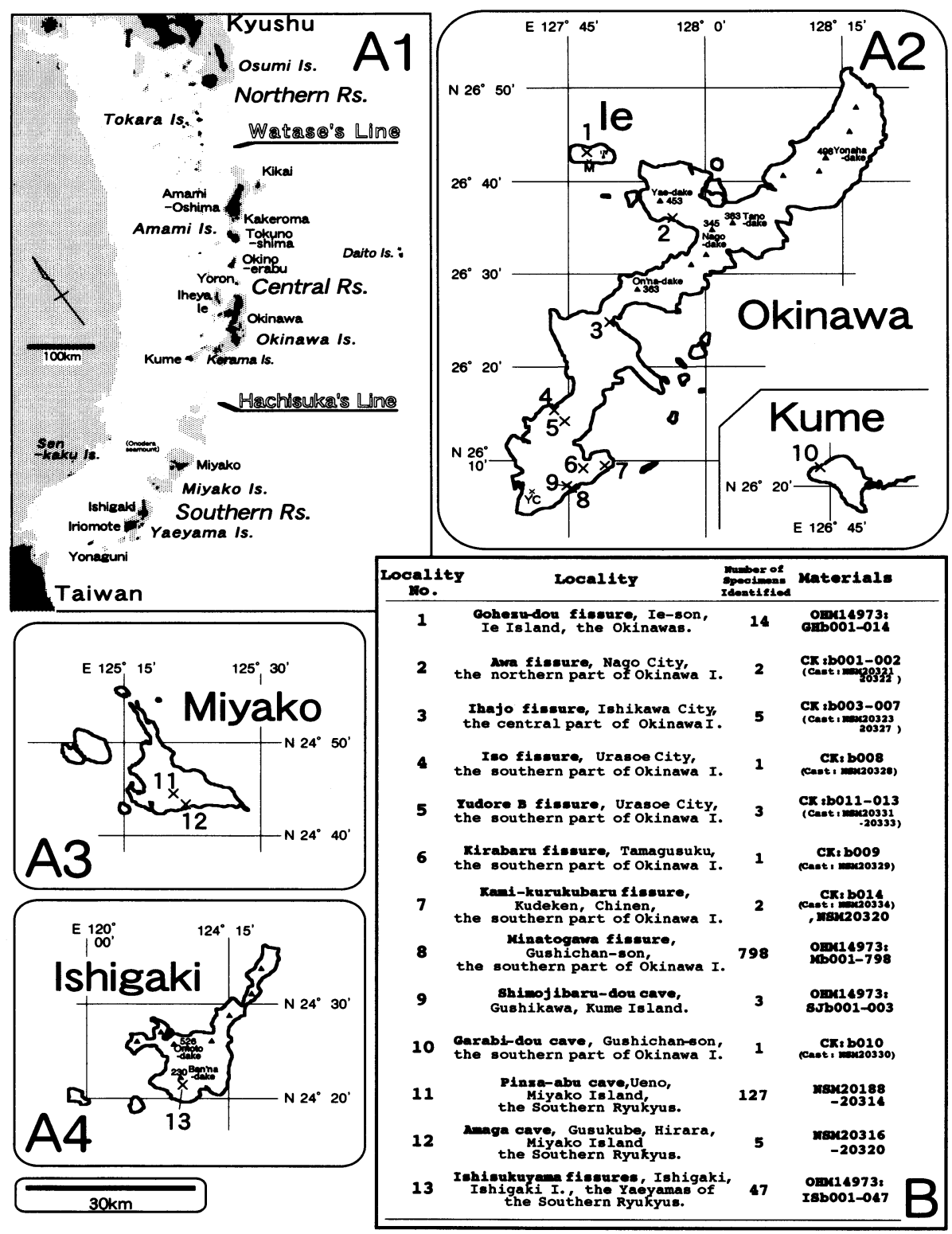

Fig. 1. Localities (A) and the Late Pleistocene avian fossils (B) of the Central and Southern Ryukyu Islands.

included in the Palaearctic region. He thus supported the chief conclusion of Hachisuka (1926), i.e., that for birds the boundary between the Oriental and Palaearctic regions is located between the Southern Ryukyus and the Central Ryukyus, and he named the boundary "Hachisuka's line" (Yamashina, 1955).

The other enigma of avian zoogeography is the "patchy" distribution of endemic birds in contrast to endemic species of other tetrapods inhabiting the Amamis and Okinawas. For example, Garrulus 
Table 1. The Late Pleistocene fossil record of birds of the Central and Southern Ryukyu Islands.

\begin{tabular}{|c|c|c|c|c|c|c|c|c|}
\hline \multirow{3}{*}{ Order } & \multirow{3}{*}{ Family } & \multirow{3}{*}{ Species } & \multirow{3}{*}{\begin{tabular}{|l} 
Yaeyamas \\
Ishigaki
\end{tabular}} & \multirow{3}{*}{$\begin{array}{l}\text { Miyakos } \\
\text { Miyako }\end{array}$} & \multicolumn{4}{|c|}{ Okinawas } \\
\hline & & & & & \multirow[b]{2}{*}{ Kume } & \multicolumn{2}{|c|}{ Okinawa } & \multirow{2}{*}{ Ie } \\
\hline & & & & & & S-C & $\mathbf{N}$ & \\
\hline Pelecaniformes & Phalacrocoracidae & Phalacrocorax filamentosus & & + & & & & \\
\hline \multirow[t]{2}{*}{ Ciconiliformes } & Ardeidae & Nycticorax caledonicus & & & & + & & \\
\hline & & gen. et sp. indet. & & & & + & & \\
\hline \multirow[t]{3}{*}{ Falconiformes } & Accipitridae & cf. Haliaeetus pelagicus & & + & & & & \\
\hline & & Butastur indicus & & + & & & & \\
\hline & & Buteo buteo & & + & & + & & \\
\hline \multirow[t]{5}{*}{ Anseriformes } & Anatidae & Anser anser & & + & & & & \\
\hline & & Alx galericulata & & + & & & & \\
\hline & & Anas falcata & & & & + & & \\
\hline & & Anas acuta & & & + & & & \\
\hline & & gen. et sp. indet. & + & & & & & \\
\hline \multirow[t]{2}{*}{ Galliformes } & Phasianidae & Coturnix japonica & & + & & & & \\
\hline & & Excalfactoria chinensis & & + & & & & \\
\hline \multirow[t]{9}{*}{ Gruiformes } & Turnicidae & Turnix suscitator & & + & & & & \\
\hline & Gruidae & Grus sp. & & & & + & & \\
\hline & & Grus sp. nov (flightless) & & + & & & & \\
\hline & Rallidae & Gallirallus okinawae & & & & + & + & \\
\hline & & Gallirallus aquaticus & & + & & & & \\
\hline & & Rallus sp. nov (flightless) & & + & & & & \\
\hline & & Porzana fusca & & + & & + & & \\
\hline & & Rallina eurizonoides & + & & & + & & \\
\hline & & Amaurornis phoenicurus & + & & & & & \\
\hline \multirow{2}{*}{\multicolumn{2}{|c|}{ Charadrilformes Scolopacidae }} & Scolopax mira & & + & & + & + & \\
\hline & & gen. et sp. indet. & & + & & & & \\
\hline \multirow[t]{4}{*}{ Columbiformes } & Columbidae & Columba janthina & & + & & + & & \\
\hline & & Streptopelia orientalis & + & + & & & & \\
\hline & & Treron formosae & & & & + & & \\
\hline & & spp. indet. & + & & & + & & \\
\hline \multirow[t]{4}{*}{ Strigiformes } & Strigidae & cf. Otus manadensis & + & & & & & \\
\hline & & Otus bakkamoena & & & & + & & \\
\hline & & cf. Strix uralensis & + & & & & & \\
\hline & & gen. et sp. indet. & & + & & & & \\
\hline Piciformes & Picidae & Sapheopipo noguchii & & & & + & & \\
\hline \multirow[t]{11}{*}{ Passeriformes } & Pycnonotidae & Hypsipetes amaurotis & + & + & & + & & \\
\hline & Muscicapidae & Erithacus sp. & & & + & & & \\
\hline & & cf. Zoothera major & & + & & + & & \\
\hline & & Turdus pallidus & + & + & & + & & \\
\hline & & Turdinae spp. indet. & & & + & + & & \\
\hline & & Sylviinae gen. et sp. indet. & & + & & & & \\
\hline & Emberizidae & gen. et sp. indet. & & + & & & & \\
\hline & Fringillidae & gen. et sp. indet. & + & & & & & \\
\hline & Corvidae & Garrulus lidthi & & & & + & & \\
\hline & & Corvus macrorhynchos & & + & & & & + \\
\hline & & Corvus "connectens" & + & + & & + & & + \\
\hline 11 orders & 17 families & $44^{+}$species & & & & & & \\
\hline
\end{tabular}

lidthi is limited to Amami-Oshima and the adjacent isles, while Sapheopipo noguchii inhabits only the "Yambaru" forest of Okinawa.

To explain this enigma, and to bring a better understanding of the avifauna of the region, we need the result of paleontology. This study focuses on reconstructing, by means of fossil records, the original distributions of the avifauna of the Ryukyus, and discusses the implications of these investigations for the avian zoogeography and ecology. 


\section{MATERIALS}

Avian fossil assemblages collected from the Late Pleistocene fissure-fills or cave deposits of the Central and Southern Ryukyus (Fig. 1), which are briefly listed in Fig. 1B, were examined for this study.

The main materials are the collections of the Okinawa Prefectural Museum, OPM14973 series, which consist of avian fossil assemblages from the Minatogawa fissure in the southern part of Okinawa, the Gohezu-dou Cave of Ie, the Shimojibaru-dou Cave of Kume and the Ishisukuyama fissures of Ishigaki. The avian fossil assemblages of Miyako, which are from Pinza-abu Cave and Amaga Cave, are in the collections of the National Science Museum, Tokyo. Some crane materials from the Kami-Kurukubaru fissure, in the southern part of Okinawa, are in the collections of the Department of Earth and Environmental Sciences, Faculty of Science, Kagoshima University. In addition to these collections, parts of the Minatogawa fossil collections of the late Mr. Seiho Oyama of Naha City and of Mr. Chokei Kishaba were also examined. Casts from these private collections are stored in the National Science Museum, Tokyo.

Identifications were carried out through comparisons to osteological specimens of recent birds, which are stored in the Okinawa Prefectural Museum, the National Science Museum, Tokyo, as well as specimens from the author's collection. Specimens from the Division of Birds, National Museum of Natural History, Smithsonian Institution were also examined for determining some species. Taxonomic names are mainly based on Howard \& Moore (1994), except in the case of some endemic birds. Information on the distributional range are mainly from Okinawa yacho kenkyu-kai (1993) and Amami ornithologists' club (1997).

\section{LOCALITIES}

The Late Pleistocene avian fossil assemblages of Ie, Okinawa, Kume, Miyako and Ishigaki in the Central and Southern Ryukyus (Fig. 1) were surveyed in this study, and 44 species of birds, included in 17 families from 11 orders, were identified (Table 1).

Dates of fossiliferous fissure-fill and cave deposits of the Ryukyus are, as far is known, concentrated within the range 10-30 Ka, i. e., within the period of the last glacial maximum. It seems therefore that all these deposits were formed at roughly the same time, under a similar environment.

Okinawa, Miyako, and Ishigaki are especially important because they yielded the fossils of zoogeographically significant species of bird.

\section{Okinawa Island}

Okinawa (Fig. 1: A-2), $1185 \mathrm{~km}^{2}$ in area, is the largest island in the Ryukyus, and is located in the middle of the archipelago. It is a narrow island and elongated in the direction of NE-SW, about 100 $\mathrm{km}$ long and narrower than $15 \mathrm{~km}$ except for the peninsular part. The highest peak is Yonaha-dake, which is $498 \mathrm{~m}$ high. Okinawa can be divided into two areas, the northern part and the southern part (or southern and central parts), geologically and geographically.

The northern part of Okinawa is pre-Neogene in geology, and is a mountainous area currently covered by a subtropical evergreen broad-leaved forest called "Yambaru". It has a unique fauna with many 
endemics. However, the Yambaru is now under heavy exploitation and/or devastation.

The southern part of the island consists, in general, the Pliocene Shimajiri Group which consists of thick siltstones unconformably overlain by Pleistocene "Ryukyu limestone". The youngest member of the Ryukyu limestone is the Minatogawa limestone, deposited during the last interglacial stage. This part of Okinawa is flat and low, at most $200 \mathrm{~m}$ above sea level, with much agriculture and dense population. Caves and fissures are well developed in the Ryukyu limestone, and are frequently fossiliferous (Oshiro \& Nohara, 1977).

The Minatogawa fissure fill deposit, which is famous for the discovery of "Minatogawa Man" (Suzuki \& Hanihara ed., 1982), contains one of the richest avian fossil assemblages in the Ryukyus.

The sediment filling the Minatogawa fissure has yielded numerous fossils of terrestrial vertebrates. Radiocarbon dating of wood fragments found near the human remains produced dates of 18,250 +/- 650 BP and 16,600 +/- 300 BP (Suzuki \& Tanabe, 1982), which indicates the age of deposition was the last glacial maximum.

The Minatogawa avian fossil assemblage is characterized by forest species, especially ground dwellers. Scolopax mira and Gallirallus okinawae are typical examples; their fossils are by far the most characteristic in this assemblage, in both number of specimens and minimum number of individuals. The modes of occurrence of vertebrate fossils of Minatogawa indicate that the fissure acted as a natural trap for animals walking around in the forest.

The "surprising" co-occurrence of some species at Minatogawa, such as Garrulus lidthi, a large thrush similar or identical to Zoothera major, and Nycticorax caledonicus are very important. The two first-named species are today found only on Amami-Oshima and adjacent isles. $N$. caledonicus, by contrast, is a "southern" element that does not inhabit Okinawa today.

Other fossil localities of Okinawa also provide important records for the native distributions of birds. Awa fissure of Nago in the northern part (Gallirallus okinawae and Scolopax mira), Ihajo fissure of Ishikawa in the central part (Sapheopipo noguchii), Yudore B fissure of Urasoe in the southern part (S. mira) and Garabi-dou Cave of Gushikami in the southern part (G. okinawae) are all localities which have yielded fossils of endemic birds.

A weakly ossified fossil femur of Rallina eurizonoides (Banded Crake) was collected from the Kami-Kurukubaru fissure of Chinen in the southern part. $R$. eurizonoides is a typical Oriental bird and breeding evidence plays an important role for avian zoogeography.

Cranes, collected from Ihajo and Kami-Kurukubaru, are a significant Palaearctic element. But the fossil crane of Okinawa is probably an extinct, and undescribed, insular endemic species that seems to have favored ground-dwelling over long distance flight. Miyako, as it will be mentioned again later, had another insular crane but it is clearly a different species from the Okinawan. Flightlessness in birds gives important information on the geographical relationships of islands to mainlands.

\section{Miyako Island}

Miyako (Fig. 1: A-3) is located at the northwest end of the Southern Ryukyus, about $250 \mathrm{~km}$ from the southern part of Okinawa and about $100 \mathrm{~km}$ from Ishigaki. The island is about $160 \mathrm{~km}^{2}$ in area. Almost the whole island consists of Ryukyu limestone. Thus Miyako is a low and flat island, with the highest point only $115 \mathrm{~m}$ above sea level. At present, the vegetation is thin and fauna is poor.

The fossiliferous deposit in Pinza-abu Cave, Ueno (Department of Education, Okinawa 
Prefectural Government, 1985) yielded a diversified and unique fossil assemblage. Radiocarbon dating of wood from the site yielded dates of $25,800+/-900 \mathrm{BP}$ and 26,800 +/- $1300 \mathrm{BP}$ (Hamada, 1985).

The Pinza-abu fossil assemblage is very significant for the paleo-zoogeography of the Ryukyus. For example, the deer fossils from Pinza-abu all belong to Capreolus miyakoensis Otsuka, 1973 (Zhen \& Hasegawa, 1985), and no remains of the two common species of the Ryukyus, Cervus astylodon and Dicrocerus? sp., were recovered. Other fossil localities in Miyako do not yield these species either. Capreolus, which occurs only in Miyako within the Ryukyus, is a typical Palaearctic deer. The mice, Microtus fortis and M. oeconomus (Arvicolidae), are also Palaearctic elements (Kaneko \& Hasegawa, 1995). It seems that Late Pleistocene Miyako developed a peculiar fauna which was under strong influence from continental Palaearctic elements, and in this respect differ from the rest of the Ryukyus.

25 species of birds, representing 14 families in 9 orders, were identified from Pinza-abu. The avian fossil assemblage generally indicates a paleoenvironment of lush vegetation near water, which is consistent with the aspect of the rodent fauna (Hasegawa, 1985; Kaneko \& Hasegawa, 1995).

The richness of Oriental birds, such as rails, Turnix suscitator and Excalfactoria chinensis, is remarkable. Coturnix japonica is very rare in the recent Ryukyus, but the archipelago, it seems, used to be a part of its migration range during times of lowered sea level. The Miyakos is important as a base for migration of Butastur indicus today. The fossil occurrence of $B$. indicus from Pinza-abu possibly suggests that the base status of the Miyakos for this eagle might have originated since before the Late Pleistocene.

On the other hand, crane and large Corvus macrorhynchos, which are Palaearctic elements, are also characteristic. Pinza-abu is one of the examples which shows the coexistence of two "Jungle Crows". Palaearctic elements were possibly "southing" because of colder stage.

The crane is a small insular species, which is undescribed. It was an endemic of Miyako, with low ability for long distance flight. This crane and the other undescribed endemic of Miyako, Gallirallus rail of ground dwelling habit, makes it evident that Miyako was isolated from Okinawa and Yaeyamas by the Late Pleistocene.

The occurrences of Scolopax mira and a large thrush cf. Zoothera major are "unexpected" indeed. These are the first records of these birds outside of the Central Ryukyus.

This study examined the same collection as did Ono \& Hasegawa (1985). Some corrections to the faunal list are needed, as follows. Their Anas sp., Rallus cf. okinawae and Scolopax cf. rusticola are Aix galericulata, Gallirallus sp. nov and Scolopax mira, respectively. Fullica atra, Rallina eurizonoides, Gallinura chloropus, Fullica? sp. and Sterna sp. in their list are doubtful and perhaps nonexistent. Though they listed two strigids, Strix sp. and Asio cf. otus, the present author recognized only one strigid in this study, which is indeterminable as to genus (but it is not Strix nor Asio, at least). One of their Buteo buteo specimens (specimen shown in their Pl. 4-7) is Butastur indicus. Corvus macrorhynchos should be divided into two, the larger type of $C$. macrorhynchos and $C$. "connectens".

\section{Ishigaki Island}

Ishigaki (Fig. 1: A-4) is one of the two main islands of the Yaeyamas as well as western Iriomote. It is about $350 \mathrm{~km}$ from Naha in Okinawa to the southwest, and about $200 \mathrm{~km}$ from Taiwan to the east. The northern half of Ishigaki is Pre-Tertiary, and the southern part is the Pleistocene Ryukyu 


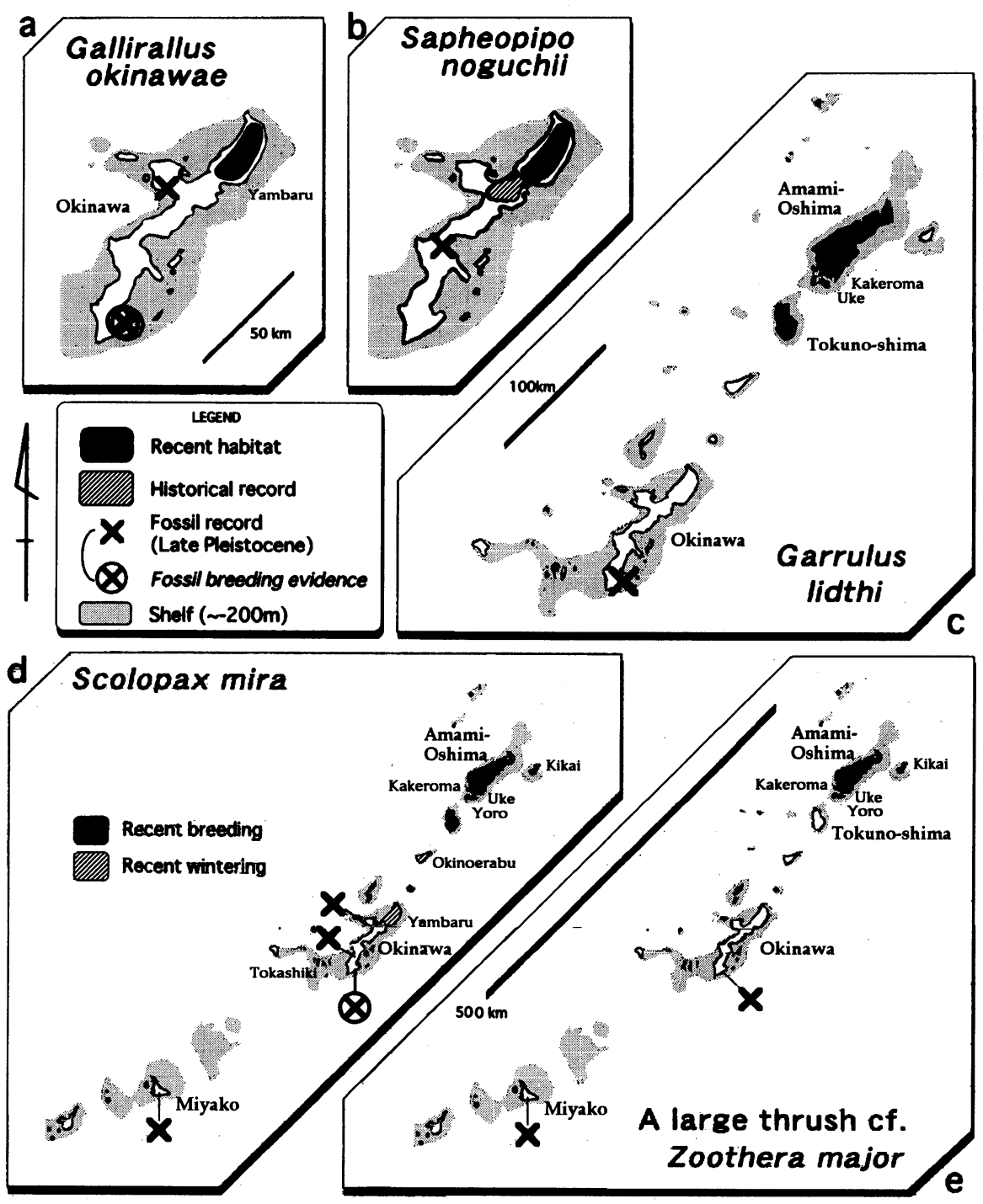

Fig. 2. Late Pleistocene fossil record of endemic birds of Central Ryukyus. a, Gallirallus okinawae; b, Sapheopipo noguchii; c, Garrulus lidthi; d, Scolopax mira; e, Zoothera major.

limestone which covers the Pre-Tertiary unconformably. The high hills in the north are Pre-Tertiary. The highest is Omoto-dake, which is $526 \mathrm{~m}$ above sea level. The sea between Ishigaki and Iriomote and the surrounding area is shallow, and so the Yaeyamas would have made one large island during times of lowered sea level. However, the Yaeyamas would never have been connected with the Miyakos or surrounding islets at any time.

The Ishisukuyama fissures (Department of Education, Okinawa Prefectural Government, 1978) were found in Eocene limestone south of Ban'na-dake peak, which has been mined heavily. The fossil assemblage (Hasegawa \& Nohara, 1978) is characterized by the occurrence of Cervus astylodon, and, 
remarkably, frogs.

11 species representing 8 families from 5 orders were identified in the Ishisukuyama material. The avian fossil assemblage consists of Oriental birds, except for the strigid species cf. Strix uralensis. It is very interesting that the Corvus fossils are of $C$. "connectens", not $C$. "osai" which is resident in the Yaeyamas today. This fact is important for the systematics of the "jungle crows" of the Ryukyus. The coexistence of two types of crows is recorded for the Okinawas and Pinza-abu of Miyako as well, but this matter will be discussed elsewhere.

This study examined the same collection as Hasegawa \& Nohara (1978). Some corrections to the faunal list are necessary. Corvus fossils are all of $C$. "connectens", though the former report identified two species, $C$. macrorhynchos and $C$. corone. Their Strunus sp. and Hypsipetes amaurotis fossils are misidentified Turdus pallidus, but there is another specimen in the collection which is of Hypsipetes amaurotis. Their "Fringillidae" in the present report is simply listed as "Passeriformes". Garrulus gladarius and Picidae, gen. et sp. indet. in their list are doubtful. The present author did not use phalanges for identification purposes because they are not readily identifiable. Thus "Falconiformes, gen. et sp. indet.", which depends on an ungual phalanx, in their list is uncertain.

\section{FOSSIL RECORDS}

\section{A: ENDEMIC SPECIES (Fig. 2)}

Fortunately, the five most important endemic species of birds, Gallirallus okinawae (Okinawa Rail), Scolopax mira (Amami Woodcock), Sapheopipo noguchii (Pryer's Woodpecker), Zoothera major (Amami Thrush), and Garrulus lidthi (Purple Jay), all have fossil records. (For Zoothera major, which must be identical to the fossil large thrush, however, no recent osteological specimen exists, so it was impossible to compare fossil material with the species directly.) These fossil records are essential for establishing the original distributional range of the endemics.

\section{Gallirallus okinawae (Okinawa Rail)}

Gallirallus okinawae is a flightless endemic, inhabiting only the "Yambaru" mountainous evergreen forest of the northern part of Okinawa today. Its prime habitat is near grassy and swampy areas, and it nests on grassy ground. It can be said that the rail prefers relatively open environments, because it is frequently observed along roads at the forest edge, in agricultural lands and even in the neighborhood of human houses. The number of individuals is estimated about 1800 today (Stattersfield, et al., 1998: all the following estimates of endemics stem from this source).

G. okinawae, which was discovered and scientifically described (Yamashina \& Mano, 1981) quite recently, does not have any reliable historical records. The archaeological record does not provide any information either, unfortunately. However, there is some anecdotal evidence indicating that this bird was distributed widely in the central part of Okinawa before World War II.

Paleontologically, fossils have been found in Awa fissure near Nago City (in the northern part of Okinawa) and Minatogawa fissure and Garabi-dou Cave in Gushikami-son (in the southern part of the island) (Fig. 2a).

The first implication of these fossil records concerns timing of speciation. Species of rails can 


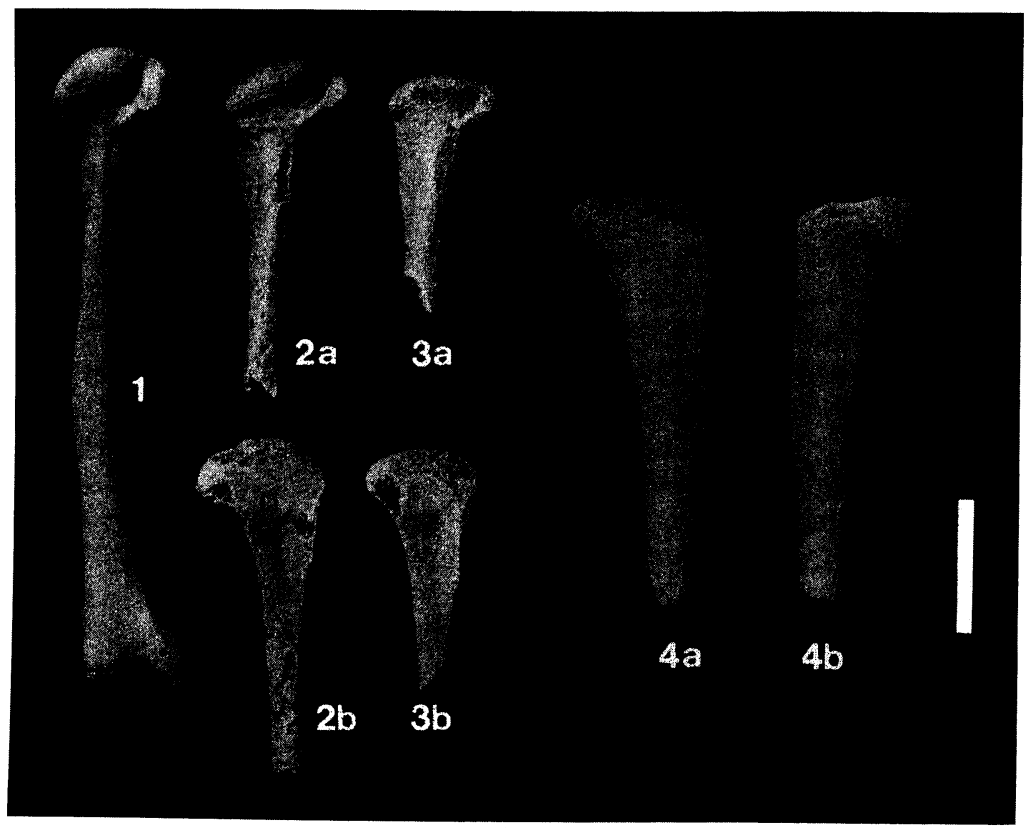

Fig. 3. Late Pleistocene fossil evidences of breeding of Gallirallus okinawae in the southern part of Okinawa. 1. Anconal view of a completely ossified left humerus, OPM14973Mb0167. 2. Proximal part of a weakly ossified left humerus, Mb0159: a, anconal view; $b$, palmar view. 3. Proximal part of a much weakly ossified left humerus, Mb0228: a, anconal view; b, palmar view. 4. Proximal part of a weakly ossified left femur, from Mr. C. Kishaba's collection (cast NSM20330): a, anterior view; b, posterior view. 1, 2, and 3 are from Minatogawa fissure; 4 is from Garabi-dou Cave. Scale bar is $10 \mathrm{~mm}$ long.

become flightless in a very short time span (Olson, 1973). Certain fossil records of Gallirallus okinawae from the Upper Pleistocene indicate that the speciation of $G$. okinawae, derived from $G$. torquatus, occurring today from the Philippines south to Sulawesi and east to northwestern New Guinea (Ripley, 1984), presumably occurred prior to the Late Pleistocene.

The position of fossil localities indicates that this bird was distributed across the whole island. In addition, two localities in southern Okinawa (Minatogawa and Garabi-dou) present evidence of ancient breeding populations in the neighborhood. Weakly ossified but identifiable fossils of young individuals (Fig. 3) occur at these two localities. These fossil assemblages, collected from the fissure fill deposits, can be regarded as autochthonous; i.e., animals fell into or dropped into fissures directly rather than through redeposition.

G. okinawae is the second most dominant element next to Scolopax mira in the avian fossil assemblage from Minatogawa fissure (25\% of 800 identifiable elements). This bird was undoubtedly common and breeding in the southern part of Okinawa during the Late Pleistocene.

\section{Sapheopipo noguchii (Pryer's Woodpecker)}

Sapheopipo noguchii is an endemic of the Yambaru of Okinawa, and lives in the deepest part of forest with mature trees higher than $10 \mathrm{~m}$. This is because this species needs old trees to make a hole for nesting. So $S$. noguchii can be treated as a bird of core forest, while Gallirallus okinawae prefers grassy ground and habitat along the edge of forest. 

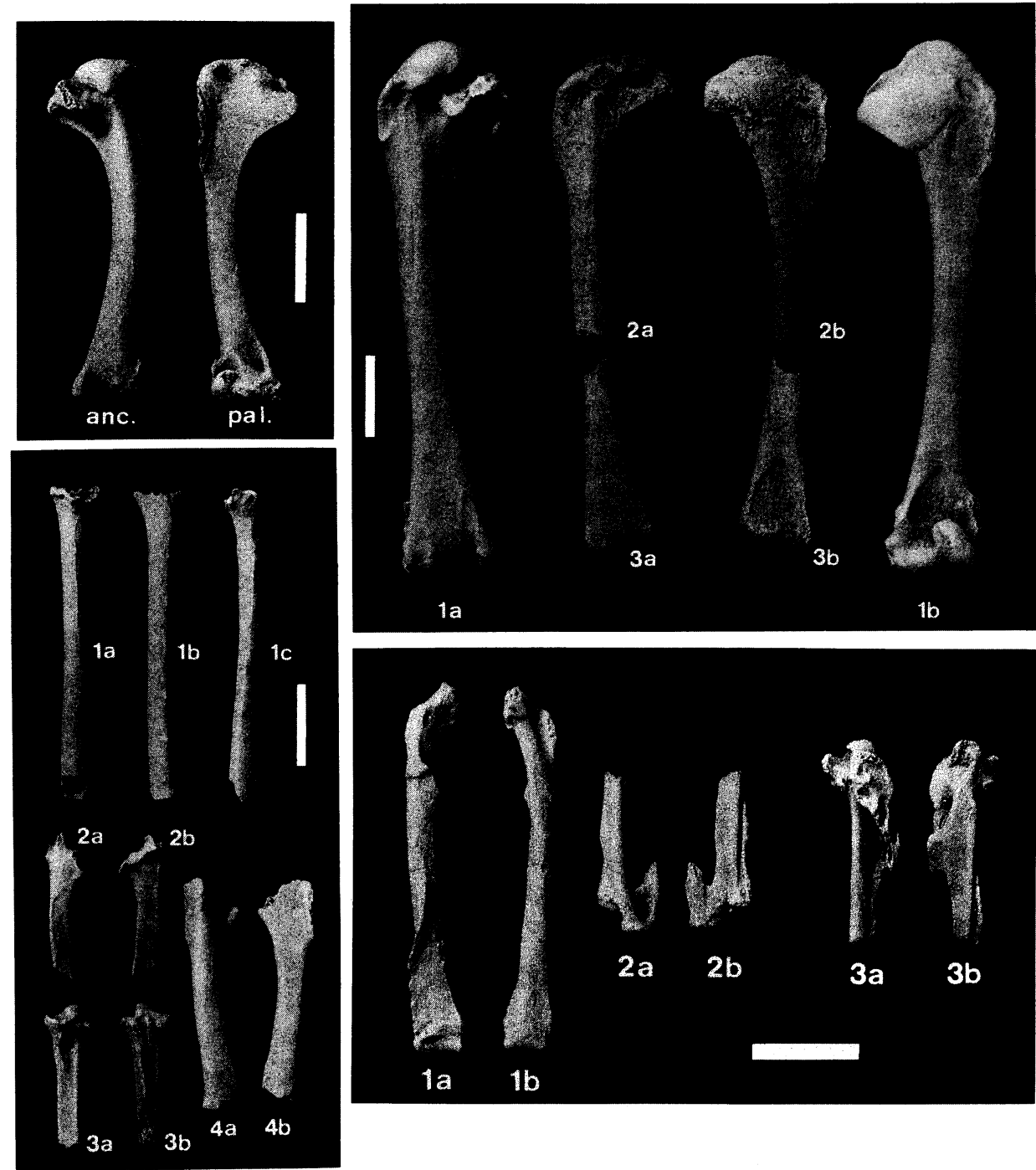

Fig. 4. Fossil bird records. (A) Fossil right humerus of Sapheopipo noguchii from Ihajo fissure-fill deposit, Ishikawa, the central part of Okinawa. A specimen from Mr. C. Kishaba's collection (cast NSM20323). anc., anconal view; pal., palmar view. Scale bar is $10 \mathrm{~mm}$ long. (B) Fossils of Garrulus lidthi from Minatogawa fissure-fill deposit, the southern part of Okinawa. 1. Left ulna lacking both proximal and distal end, OPM14973-Mb0131: a, palmar view; b, anconal view; c, external view. 2. Right scapula lacking blade, Mb0132: a, dorsal view; b, ventral view. 3. The proximal part of left tarsometatarsus, from the Oyamas' collection (cast NSM): a, anterior view; b, posterior view. 4. Shaft of left humerus, Mb0129: a, anconal view; b, palmar view. Scale bar is $10 \mathrm{~mm}$ long. (C) Late Pleistocene fossil evidences of breeding of Scolopax mira from Minatogawa fissure-fill deposit, the southern part of Okinawa. 1. Anconal view of a completely ossified left humerus, OPM14973-Mb0288: a, anconal view; b, palmar view. 2. Proximal part of a weakly ossified left humerus, Mb0089: a, anconal view; $b$, palmar view. 3. Distal part of a weakly ossified left humerus, Mb0504: a, anconal view; b, palmar view. Scale bar is $10 \mathrm{~mm}$ long. (D) Fossils of a large thrush cf. Zoothera major from Minatogawa fissure in southern part of Okinawa (1 and 2) and Pinza-abu Cave in Miyako (3). 1. Left coracoid, OPM14973-Mb0786: a, dorsal view; b, ventral view. 2. Distal fragment of right carpometacarpus, Mb0126: a, internal view; b, external view. 3. Proximal part of right carpometacarpus, NSM20307: a, internal view; $b$, external view. Scale bar is $10 \mathrm{~mm}$ long. 
The devastation and exploitation of forests after World War II put this bird into a corner. The recent distribution is restricted to the deep Kunigami Hills, though until the 1940's it used to live also around Nago-dake Hill (Tamagusuku \& Nakamura, 1988). The estimated number of individuals is only about 100 making it the most endangered species in the Ryukyus next to Zoothera major from Amami-Oshima.

A humerus (Fig. 4:A) from Ihajo, Ishikawa City is the only fossil record of $S$. noguchii. This occurrence (Fig. 2b) is evidence of an ancient, wider distribution that include the central part of Okinawa, where the bird does not occur now or during the recent past.

\section{Garrulus lidthi (Purple Jay)}

Today, Garrulus lidthi, a beautiful jay, inhabits Amami-Oshima and adjacent isles of Uke and Kakeroma. It used to inhabit Tokunoshima historically. Amami-Oshima is covered by relatively welldeveloped forests. $G$. lidthi is distributed widely in younger as well as mature forest. The current population is estimated to consist of approximately 5800 individuals.

Nine fossil specimens, representing at least two individuals (Fig. 4:B), have been found at Minatogawa (Fig. 2c). This discovery indicates that $G$. lidthi used to have a distributional range throughout the Central Ryukyus at least until the Late Pleistocene. This find also verifies the close zoogeographical relationship between the Amamis and the Okinawas.

\section{Scolopax mira (Amami Woodcock)}

Scolopax mira has also been treated frequently as a subspecies, $S$. rusticola mira. However, it can be clearly distinguished from $S$. rusticola by its much larger body and wider bill. It is a resident of Amami-Oshima and the adjacent islands of Kakeroma, Uke, Yoro, and Tokunoshima, which were formerly regarded as being inhabited by $S$. mira solely. But the northern part of Okinawa has yielded numerous observation records of the species in the last two decades, showing that it may be a resident of this area too. However, reliable breeding records are limited to the Amamis (Amami-Oshima and Tokunoshima). Migratory populations appear in winter on the islands of the Central Ryukyus such as Kikai, Okinoerabu, and the northern part of Okinawa and so on. S. mira inhabits evergreen forests and walks around open spaces to find food at night. It stays motionless on the forest floor during the daytime.

Okinawa has yielded fossil records of $S$. mira from Awa in Nago City and Minatogawa (Fig. 2d). In the avian fossil assemblage of Minatogawa, almost $70 \%$ of specimens are $S$. mira. This overwhelming volume may evidence that $S$. mira was originally very common in the southern part of Okinawa. However, the result is probably taphonomically biased because $S$. mira is a ground dweller, and therefore very likely to end up in fissure fill deposits.

S. mira materials from Minatogawa include weakly ossified specimens of young birds (Fig. 4:C), indicating that breeding took place around this fissure. The fossils indicate that $S$. mira was common and even capable of breeding in the southern part of Okinawa during the Late Pleistocene though its recent breeding is restricted to the Amamis.

Fossils of $S$. mira occurred in Pinza-abu Cave in Miyako, in the Southern Ryukyus as well (Fig. 2d). These fossils are the first records of this bird outside the Central Ryukyus. It evidences that $S$. mira used to have a wider distributional range in the Southern Ryukyus during the Late Pleistocene than it does today. No weakly ossified specimens were encountered at Pinza-abu, so it is uncertain whether or not this bird bred in Miyakos. At present, fossil evidence only reveals that the recent 
distribution of $S$. mira, with its center in the Amamis and extending south to the Okinawas, is possibly a reduced version of its Late Pleistocene native pattern, located in the Central Ryukyus and extending into the southern Miyakos.

\section{cf. Zoothera major (Amami Thrush)}

An almost complete left coracoid and some other fragmentary fossils from Minatogawa (Fig. 4: D-1, 2) indicate the previous presence of a rather large thrush on Okinawa. These materials are about $10 \%$ larger than the elements of Zoothera dauma, the largest thrush of Japan except $Z$. major. Unfortunately, no osteological specimen of $Z$. major was available for study and so it has been impossible to compare them directly. But the close relationship between the Amamis and the Okinawas, which is reinforced by the occurrence of Garrulus lidthi, lead me to believe that the fossil large thrush is identical to $Z$. major.

Another fossil of a large thrush was recovered from the Pinza-abu Cave in Miyako (Fig. 4: D-3a, 3b). The specimen indicates the about $10 \%$ larger size to compare with the element of $Z$. dauma too, and so, though the materials are quite incomplete, it seems that the fossils of Okinawa and Miyako are of one species. If so, this is additional evidence that the endemic bird of the Central Ryukyus once had a wide distribution in the Southern Ryukyus (Fig. 2e).

The Amami Thrush is an endemic full species (Zoothera major), though it is frequently treated as a subspecies of $Z$. dauma (Z.d. amami). These two are clearly distinguished by their morphologies and modes of life. It is estimated that the number of individuals is no more than 100 , and it is the most endemic and endangered member of the avifauna of the Ryukyus today.

\section{DISCUSSION A}

\section{Palaeoendemism in the Recent Distribution Pattern}

The five endemics of the Central Ryukyus, which tend to inhabit one island only, all have fossil representatives outside their recent distributional ranges (Fig. 2). It is obvious that these fossil records are not evidence of "change" of habitats but are instead evidence of ancient wider ranges and recent relic distributions, because of the close relation between the Okinawas and the Amamis (though Amami-Oshima and Yambaru themselves do not yield fossils of these Pleistocene birds).

The fossil occurrences of Scolopax mira and a large thrush cf. Zoothera major from Miyako are very interesting in considering the geographical relationship between the Central Ryukyus and the Miyakos. These two birds indicate the close zoogeographical relationship between the Central Ryukyus and Miyako. Further, Diplothrix legata, an endemic large tree rat, inhabits evergreen forest on Amami-Oshima, Tokunoshima and Okinawa today. This species has also recorded from fossil sites in Miyako (Hasegawa, 1985).

The paleoavifauna of Miyako, on the other hand, includes two extinct flightless (or nearly flightless) birds, a crane and a rail; both are undescribed new species. The rail, Gallirallus sp. nov, is not $G$. okinawae, while the new rail of Miyako may also have evolved from $G$. torquatus as $G$. okinawae did. The crane and rail are endemics of Miyako, having never been found on the other islands. The Okinawan flightless bird, G. okinawae, never occurred on Miyako, of course. These paleornithological facts indicate that the Miyakos had already been long isolated geographically from 
the other islands, at least, during the Late Pleistocene.

The fossil assemblage of Pinza-abu is somewhat enigmatic; it is characterized by Palaearctic animals, including some very large mammals (Zhen \& Hasegawa, 1983; Hayashi, 1985; Kawashima, et al., 1985). This is unusual for an insular fauna. Miyako has only yielded the fossil roe deer, Capreolus miyakoensis (Hasegawa, et al., 1973). The largest individuals surpass the largest members of recent roe deer on record (Zhen \& Hasegawa, 1985). The wild boar, Sus sp., shows similarity to the larger population of the main islands of Japan, not to the smaller populations of the Ryukyus, in size and dental morphology (Hayashi, 1985; Kawashima, et al., 1985).

It seems unlikely the Miyako was the only island in the Ryukyus that would have been periodically connected with the mainland. More plausibly, the seamounts that lie between the Miyakos and Taisho Island (e.g., Onodera Seamount) could have been subaerial from time to time (especially if they have recently have undergone tectonic subsidence). In that way, they could have acted as "stepping stones" keeping the Miyakos in touch with the continent during the Late Pleistocene.

\section{CONCLUSION A}

The present examination of the fossil records of endemic birds leads to the following conclusions.

1; the Okinawas and the Amamis had continuous forest in which the endemics lived during the Late Pleistocene. At this time breeding in Scolopax mira (only on the Amamis today) and Gallirallus okinawae (within "Yambaru" only) took place in the southern part of Okinawa.

2; the fossil occurrences of Scolopax mira and a large thrush cf. Zoothera major from Miyako are evidence of the much wider distribution of these birds in the past, and they suggest faunal contact between the Central Ryukyus and the Miyakos.

3; Miyako, on the other hand, had a unique paleoavifauna including endemic flightless birds. It seems that the Miyakos had already been isolated geographically at that time, and, had periodical connection to continent.

\section{B: ORIENTAL SPECIES}

Birds of wider distribution also show the same phenomenon, as their fossils occur on presently uninhabited islands. However, the paleoavifauna of the Ryukyus consists mainly of residents and visitors, or stragglers which are recorded historically even though their frequency is low, of the Ryukyus, and so foreign species are seldom encountered.

But still some fossil records give important suggestions for the form of avian zoogeographical regions during the Late Pleistocene. The following are records limited to the northern end of the Oriental region in relation to the Hachisuka's line between the Southern Ryukyus and the Central Ryukyus:

\section{Nycticorax caledonicus (Rufous Night-Heron) on Okinawa}

The greatest departure from the recent range concerns the fossil occurrence of Nycticorax caledonicus at the Minatogawa fissure (Fig. 5). N. caledonicus resides in the Philippines south to Indonesia, Melanesia, Australia, and Micronesia, inhabiting the mangrove estuaries.

Though fragmentary, the fossil is identifiable from such osteological characters as well expanded 


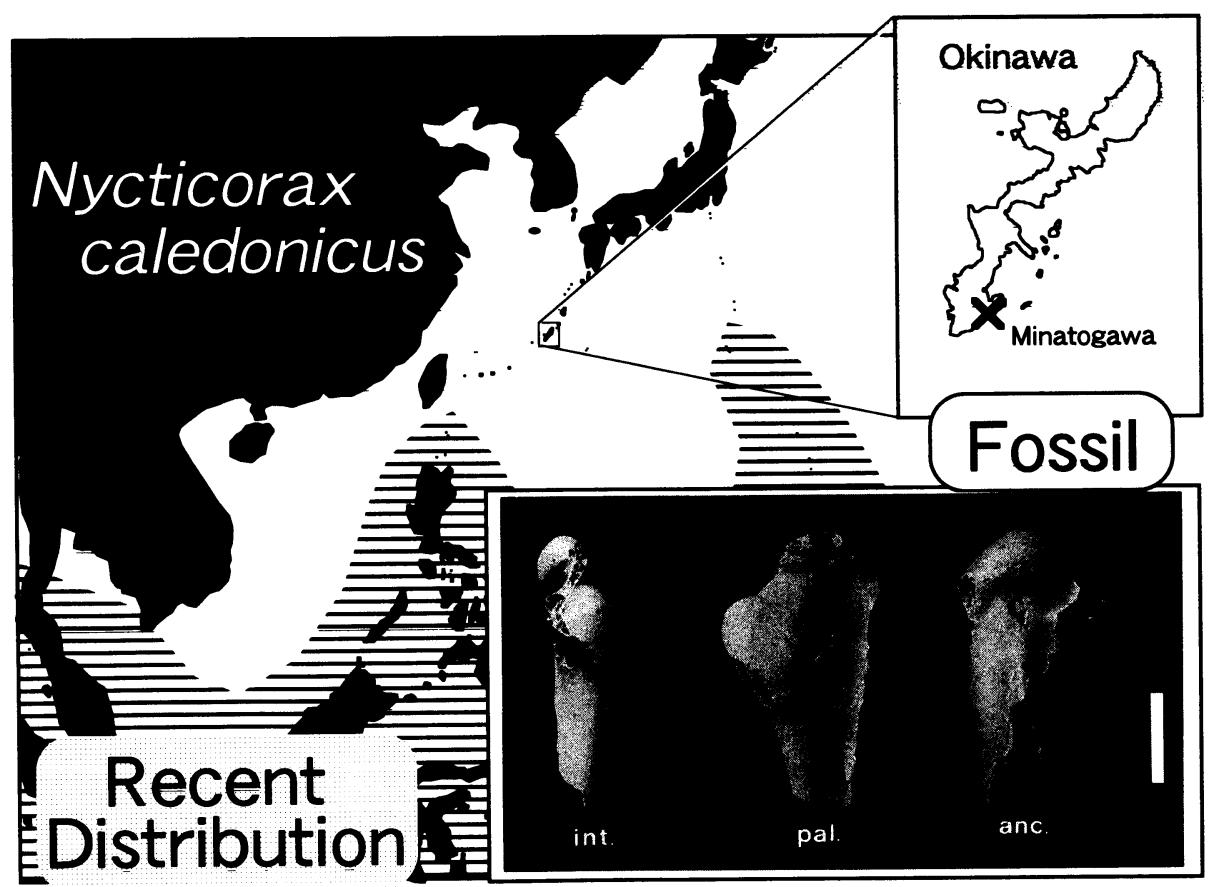

Fig. 5. Fossil record of Nycticorax caledonicus. Fossil proximal end part of a left humerus, OPM14973Mb0135, is from Minatogawa fissure in southern part of Okinawa. Abbreviations: int., internal view; pal., palmar view; anc., anconal view. Scale bar is $10 \mathrm{~mm}$ long.

bicipital surface, thick deltoid crest, deep and oval attachment of supraspinatus etc. This is the first record of $N$. caledonicus from Japan except an extinct (last record, 1889) endemic subspecies $N$. $c$. crassirostris of the Ogasawaras (the Bonins). $N$. c. crassirostris is characterized by the thick and deep bill, thus the fossil is indeterminate as to subspecies.

\section{Breeding Rallina eurizonoides (Banded Crake) on Okinawa}

Rallina eurizonoides is a typical Oriental bird, distributed from Okinawa southwards to Taiwan, Philippines, Southeast Asia and India. Because the northern limit of its residence is the Yaeyamas, it has been used as one of the grounds for accepting Hachisuka's line, i.e., the northernmost limit of Oriental avifauna in the Southern Ryukyus.

The fossil records of $R$. eurizonoides are from the Ishisukuyama fissure of Ishigaki, the Yaeyamas and the Kami-Kurukubaru fissure of the southern part of Okinawa (Table 1). The former record is reasonable zoogeographically. What is interesting is the latter.

The fossil bone from Kami-Kurukubaru is of a young individual, incompletely ossified (Fig. 6). This implies an extended breeding range for $R$. eurizonoides which included Okinawa, north of the Hachisuka's line, during the Late Pleistocene.

\section{Excalfactoria chinensis (Indian Blue Quail)}

The recent range of Excalfactoria chinensis known from Pinza-abu on Miyako is from Taiwan and south of the southern part of China. This is another example of northward sifting of an Oriental element. 


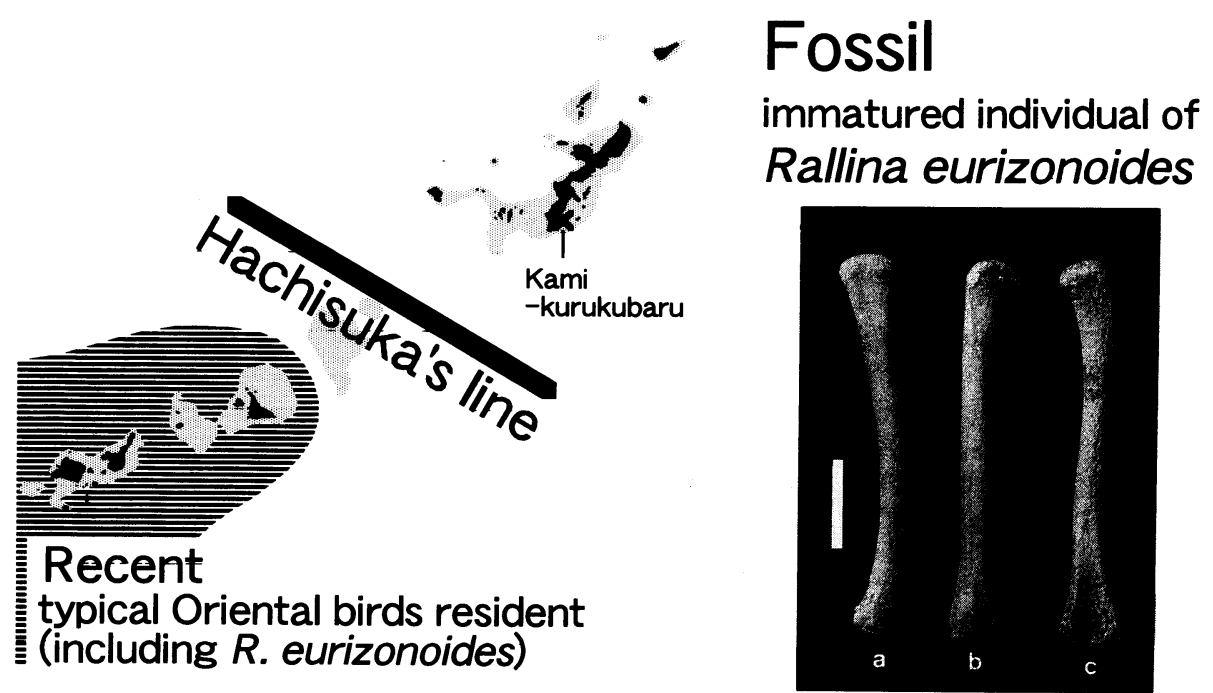

Fig. 6. Weakly ossified fossil right femur of Rallina eurizonoides from Kami-Kurukubaru fissure in the southern part of Okinawa, NSM20320: a, external view; b, anterior view; c, posterior view. Scale bar is $10 \mathrm{~mm}$ long.

\section{DISCUSSION B}

Vanished distributions and problems of regional Zoogeography (Historical zoogeography and the Oriental-Palaearctic boundary)

Because Oriental birds are typically resident as far as the Yaeyamas, the Southern Ryukyus are treated as the northern limit of the recent Oriental region, with Hachisuka's line as its northern boundary. The line in question (Yamashina, 1955) is named after M. Hachisuka, who first pointed out its importance for avifaunal zoogeography (Hachisuka, 1926).

What is unique for this line is the southern shift of avian distribution patterns as compared to that of other tetrapods (Watase's line, between the Central Ryukyus and the Northern Ryukyus. Fig. 1: A-1).

However, the fossil evidence from the Late Pleistocene suggests that the Hachisuka's line is an "artificial" boundary, produced by vanished distributions. This is evidenced by the breeding of Rallina eurizonoides, - a "typical Oriental bird"-, on Okinawa during the Late Pleistocene (Fig. 6). Okinawa has also yielded fossils of Nycticorax caledonicus, currently a resident of the Philippines and islands to the south (Fig. 5). Gallirallus okinawae evolved from G. torquatus, an Oriental rail distributed in and south of the Philippines (Yamashina \& Mano, 1981; Ripley, 1984).

Scolopax mira and possibly Zoothera major are the other examples; they once had much more extensive ranges (Central Ryukyus to the Miyako) than they do presently (Fig. 2d, e). It seems that Late Pleistocene birds never minded the Hachisuka's line.

Incidentally, though ornithologists have not mentioned this point clearly, Hachisuka's line has two implications, from the standpoint of regional (or ecological) biogeography and historical 
biogeography.

The first point is a fact that typical Oriental birds are resident as far as the Yaeyamas today, a fact known since Hachisuka (1926) mentioned it. But, the fossil records here denied this. Ornithologists now have no need to be confused even if they found typical Oriental birds breeding in Okinawa or north of it, because it is natural.

The other implication, which is historical, was signified from systematic studies of endemic birds of the Central Ryukyu Island (Yamashina, 1941, 1955). Yamashina (1955) considered a Palaearctic origin for these endemics, and one of result of his work was recognition of Hachisuka's line. But, as Morioka (1974) pointed out, the direct origins of these endemic birds is possibly been found in residents of Oriental region, even though, in general, their allies are Palaearctic elements. So, in other words, the historical implication of Hachisuka's line as understood by Yamashina (1955) may have been wrong from the beginning.

The massively endemic fauna of the Central Ryukyus is a relic unit, and a single origin for it is strongly indicated. No one may doubt the Oriental origin of endemic non-avian tetrapods in the Central Ryukyus (which is why Watase's line is accepted). Because of the fossil occurrences mentioned above, I believe and would like to propose that the boundary between the Oriental and Palaearctic regions should be Watase's line for birds too.

\section{CONCLUDING REMARKS}

\section{Formation of the Recent Avifauna of the Ryukyus: A Perspective from Paleornithology}

\section{Origin (hypothetical model) - Isolation and endemism without land bridge --}

All known fossil assemblages from the Central and Southern Ryukyus are from the Upper Pleistocene, and are thus only some tens of thousands years old. However, analysis of the systematic position of birds and historical geology of the Archipelago may allow construction of a model for the longer history of avifauna of the Ryukyus.

Ujiie (1994) explained the birth of the early Ryukyu Archipelago by depression of part of the Okinawa Trough and subsequent upheaval of part of the Archipelago during the Early Pleistocene. Because its age must go back before the transgression which produced the Pliocene Shimajiri Group, the Late Miocene fauna of the area is assumed to have been isolated passively as the archipelago became established. Granting this is true, it is consistent with the character of the fauna of the Ryukyus, which is composed of relict species and shows massive endemism. And so it is not necessary to assume "land bridges" from north or south, as many paleontologists would like to do.

The author thinks definitely that endemics such as Garrulus lidthi, Zoothera major, Scolopax mira and Sapheopipo noguchii evolved from such isolation. In addition, present taxonomy treats some Ryukyu birds "unfairly". The author feels personally that "Picoides leucotos owstoni" and "Otus bakkamoena pryeri" ("O. lempiji pryeri" in Howard \& Moore, 1994) are another case of two full species.

The other supposition concerning the avifauna of the Ryukyus is the grouping of Sapheopipo noguchii and Picoides owstoni (= P. leucotos owstoni). The view that $P$. leucotos is ancestral for Sapheopipo noguchii seems fantastic, but it has been accepted by ornithologists (e.g., Goodwin, 
Avifauna of the Ryukyu Archipelago
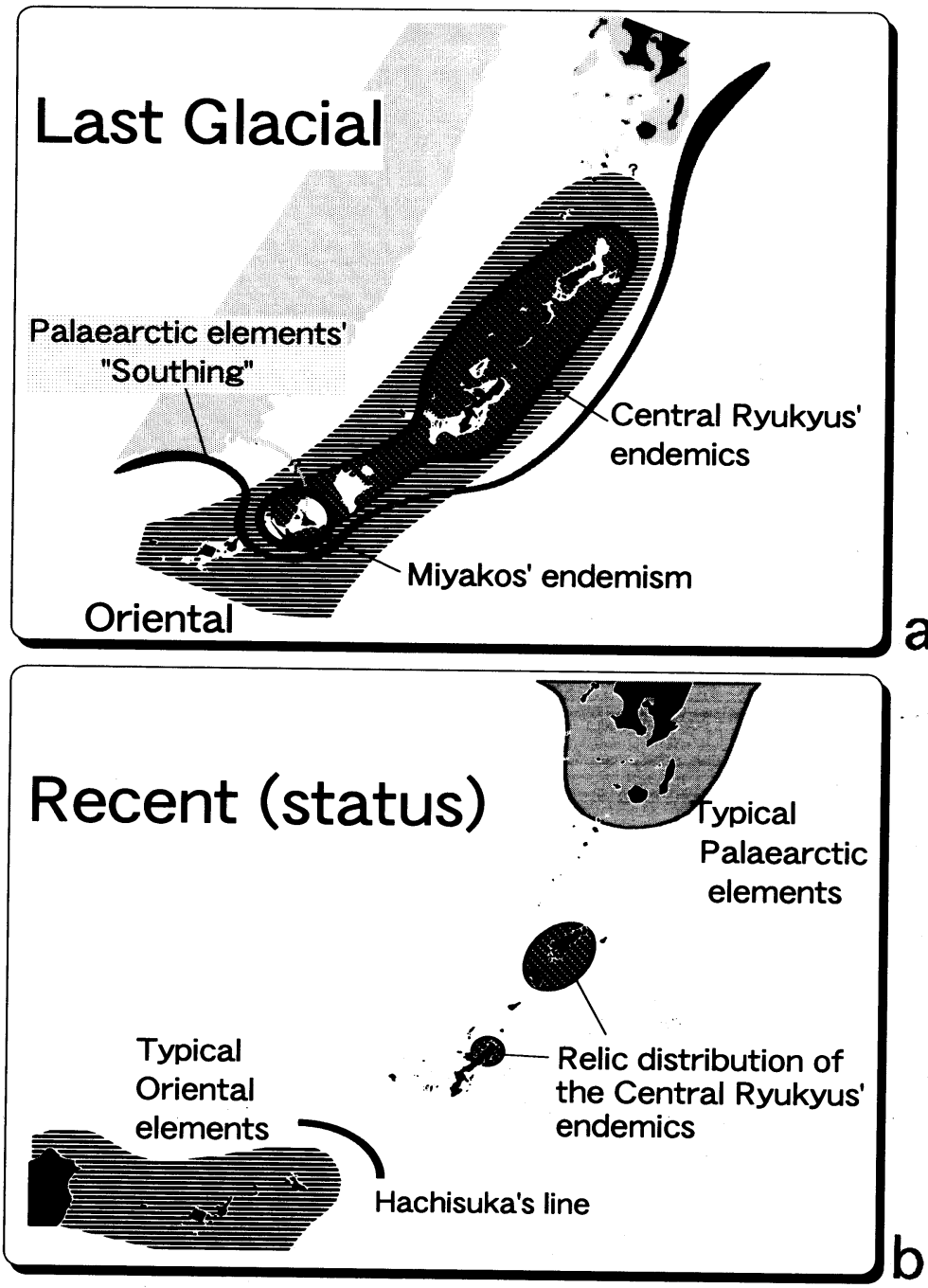

Fig. 7. Avifauna of the Ryukyu Archipelago. a. Late Pleistocene (the last glacial maximum) paleoavifauna. b. Recent status of avifauna on Ryukyus islands.

1968). Judging from the close relation of zoogeography within the Central Ryukyus, the story that the isolated population of Picoides leucotos evolved to endemic P. owstoni on the proto-Ryukyu Archipelago, and later, after the separation of the Amamis and the Okinawas, the population of Okinawa became darker and reddish in appearance, Sapheopipo noguchii, is highly probable.

\section{The Late Pleistocene paleoavifauna - Original frame of the recent pattern --}

The Late Pleistocene paleoavifauna of the Central and Southern Ryukyus was "richer" than the recent distribution pattern, and it provides a great deal of information on the formative processes that has led to the present day biota. 
Fig. $7 \mathrm{a}$ is the native Late Pleistocene avifauna of the Ryukyus that was reconstructed from the fossil records in this study. We may see how thin and precarious the recent condition is (Fig. 7b).

The Process and Mechanism Why and how did these extirpations occur? We cannot look into the future or grapple with the conservation of fauna without answering these questions in a strict sense.

However, the records in our hands are too incomplete to tell the history specifically. Frankly speaking, only two phases, before and after, are known. What we can do in the current situation is to estimate the history from the circumstances, but it must be useful.

Naturally caused extirpations? The fossils come from sediments which deposited at the last glacial maximum. Was the avifauna affected by the glacial-interglacial transition? The main changes caused by the transition were environmental change and marine transgression.

The Kuroshio warm current moves northward along the Ryukyu Archipelago. So the Ryukyus, especially the Central and Southern Ryukyus which are relatively low (highest peak, $694 \mathrm{~m}$ high Yuwan-dake on Amami-Oshima), have subtropical oceanic climate. The planktonic foraminifer fossils indicate that the sea surface temperature around the Ryukyus was about $26-28^{\circ} \mathrm{C}$ in summer and about $18-20^{\circ} \mathrm{C}$ in winter during the last glacial maximum (UNESCO/IOC Western Pacific Subcommission, 1995). This is little different from recent conditions, which feature about $27-29^{\circ} \mathrm{C}$ in summer and about $20^{\circ} \mathrm{C}$ in winter (Japan Weather Association, 1998). This also means that the climate of the Ryukyus changed very little at the glacial-interglacial transition, and hardly influenced the vegetation and fauna.

On the other hand, the drastic transgression after the Pleistocene-Holocene transition may have had a serious impact on insular faunas. The Ryukyu islands present wide shelves around the current island area, and would therefore have constituted large islands during the time of lowered sea level. It is known that the number of species on an island relates to the island's area (e.g., MacArthur \& Wilson, 1967; Higuchi, 1979). It is probable that some populations were in a sense "swallowed up" by the sea which rose rapidly after the termination of the glacial age.

Human caused extirpations? Recent paleornithological activities on the Pacific islands (e.g., Balouet \& Olson, 1989; Olson \& James, 1982; Steadman, 1985; Olson \& James, 1984; Steadman \& Olson, 1985; Steadman, 1995) have "repeatedly shown that prehistoric man has had an extremely adverse effect on insular ecosystems on a global scale. The resulting extinctions have produced completely unnatural faunal assemblages that are grossly misleading with regard both to species diversity and to biogeographical patterns." "It should be remembered that similar problems exist with other groups of organisms and with other groups of islands." And so "any assessment of an insular biota should be made with the assumption that it has experienced some degree of human-caused disturbance" (after Olson, 1990). It is probable that the Late Pleistocene fauna of Ryukyu Archipelago was also damaged by human activity.

However, humans had already inhabited the Ryukyus by the Late Pleistocene. Yamashita-cho Cave in the southern part of Okinawa, Shimojibaru-dou in Kume and Pinza-abu in Miyako as well as Minatogawa in Okinawa have records of human fossils. The femur and tibia of a child from Yamashita-cho (Suzuki, 1982) is famous as the oldest human record in the Ryukyus because the cave deposit provided a radiocarbon age of $32,000+/-1,000 \mathrm{BP}$. The Late Pleistocene paleoavifauna presented here, which is a part of the paleofauna of the Ryukyus represented by fossil deers, were associated with humans. It seems that Pleistocene man did not cause the extirpations of fauna on the 
Ryukyu islands, though it is impossible to say whether the Late Pleistocene paleofauna was already affected by human arrival itself. What is important now is to find the reason for extirpations that occurred "after the Late Pleistocene until today".

An archaeological record of birds from the Nagarabaru-Nishi midden of Ie (Hasegawa \& Ono, 1979; Educational Committee of Ie-son, 1979) is very relevant to this question. It is a Holocene record, which was formed under the same environment at the same sea level stage as today. Radiocarbon dates for wood and clams from the lowermost layer of this midden are 2,080 +/- $80 \mathrm{BP}$ and $2,060+/-80 \mathrm{BP}$.

Hasegawa \& Ono (1979) indicated that Diomedea sp. and Puffinus tenuirostris, which are rare on the Okinawas today, had been common at that time, and that especially Diomedea sp. must have been breeding in and around Ie, because these pelagic birds are difficult to catch except at breeding sites. Also, the large type of Corvus macrorhynchos and $C$. "connectens" were still coexisting at that time. The large type of $C$. macrorhynchos is not in the Central Ryukyus and southward today.

The archaeological record from Nagarabaru-Nishi midden suggests that the extirpation of these birds occurred after the time of deposition of this midden. It thus seems that increasing human activity was the reason of extirpations of birds, although it is difficult to imagine how this actually waked.

In this connection, pre-Neolithic human activity on the Central and Southern Ryukyus seems to have been very low. No artifacts have been found from Late Pleistocene fissure-fill and cave deposits of the Ryukyus, even from Minatogawa where scientists have been looking for artifacts very carefully. Further, there is no evidence of humans in the Central and Southern Ryukyus for more than ten thousand years after the Late Pleistocene fossil records until the oldest Neolithic sites. So perhaps human evacuated the Ryukyu islands during the long blank period. These facts, though they are quite negative, may be circumstantial evidence to treat how it was that only since the Neolithic age have humans produced serious impacts on the fauna on the Ryukyu islands.

\section{Today}

Both sea level change and the human activity are probably responsible for the waning of the native avifauna. However, the author himself regards the human impact as the more significant factor.

The only Okinawan endemics surviving today are Sapheopipo noguchii and Gallirallus okinawae. S. noguchii is probably a relative of Picoides owstoni (= P. leucotos owstoni), an endemic of AmamiOshima. If so, the Amamis have kept all members of the endemics which were once distributed along the whole of the Central Ryukyus during the Late Pleistocene.

It is nonsense to think that the members which are alive on Amami-Oshima $\left(720 \mathrm{~km}^{2}\right)$ today were not able to survive on Okinawa $\left(1,200 \mathrm{~km}^{2}\right)$ without the land which sank at the termination of glacial age. The author believes that it is because of higher human activity since the Neolithic age that the avifauna of Okinawa is critically endangered.

The fauna, once reduced by extinction, cannot recover to its original condition. The forests of the Amamis and Yambaru in Okinawa are very important ecological habitats. We must take their present condition into consideration for the preservation of unique ecological habitats.

ACKNOWLEDGMENTS For helps of all people mentioned below, the author would like to express his sincere thanks here. 
Doctors Takeshi Setoguchi, Kiyotaka Chinzei (currently emeritus), Fujio Masuda, Terufumi Ohno, Haruyoshi Maeda and Hidetoshi Kamiya, the staffs for paleontology of Department of Geology and Mineralogy, Graduate School of Science, Kyoto University, guided this study with instructive comments.

Dr. Yoshikazu Hasegawa, the professor emeritus of Yokohama National University, gave wholehearted supports to the author, which were essential. Messrs. Seikou Oyama, Seishin O. and Morimasa O., the sons of the late Mr. Seiho Oyama who promoted the palaeontology and paleoanthropology of Okinawa, permitted to examine the collection of their father. Mr. Chokei Kishaba supplied his fossil collection from Okinawa. The all of the Oyamas and Mr. C. Kishaba kindly received the author and his colleagues on their visiting to Okinawa. Doctors Makoto Manabe and Naoki Kohno of National Science Museum, Messrs. Koushou Kamiya and Kenji Takehara of Okinawa Prefectural Museum and Doctors Storrs L. Olson and Helen F. James of National Museum of Natural History, Smithsonian Institution offered the author convenience to examine the collection housed in the museums, and also discussed and instructed. Mr. K. Takehara also gave instructive talks on the recent fauna of the Ryukyus, and he accompanied and took care of the short trip of the author and Dr. Paul G. Davis on February '97.

The early version of this paper was read on the International Symposium "The Ryukyu Islands: The arena of adaptive radiation and extinction of island fauna", Kagoshima University, Kagoshima on 5-7 November 1998. The convener Dr. Hiroyuki Otsuka, Department of Earth and Environmental Science, Kagoshima University, gave the author opportunity to have a presentation on the symposium. The participants of the symposium discussed together and that was very suggestive.

Special thanks are due to the referees and editors.

A part of this study was supported by Research Fellowships of the Japan Society for the Promotion of Science for Young Scientists.

Besides, the author's family and Saori Matsuoka (Nakai) of Sagami High School, Tokai University who support the author all the time, were indispensable to prepare this paper.

\section{REFERENCES}

Amami Ornithologists' Club, 1997. Birds in Amami, 288 pp. Kagoshima. (in Japanese)

Balouet, J. C. \& Olson, S. L., 1989. Fossil birds from late Quaternary deposits in New Caledonia. Smithsonian Contributions to Zoology 469: 1-38.

Department of Education, Okinawa Prefectural Government, ed., 1978. Ishisukuyama. 98 pp. Okinawa. (in Japanese)

- 1985. Pinza-Abu Cave, 184 pp. Okinawa. (in Japanese)

Educational Committee of Ie-son, 1979. Preliminary reports on the 2nd survey of Pleistocene cave deposits from Gohezu limestone cave, Ie Island, Okinawa, Japan. Reports on cultural assets of Ieson (Okinawa) 5: 56 (in Japanese)

Goodwin, D., 1968. Notes on woodpeckers (Picidae). Bulletin of British Museum (Natural history), 17: $1-44$

Hachisuka, M., 1926. Avifauna of the Riukiu Islands. The Ibis 12 (2): 235-237.

Hamada, T., $1985 .{ }^{14} \mathrm{C}$ age of charcoal from Pinza-Abu Cave, deposits, Miyako Island, Okinawa, 
Japan. In: Pinza-Abu Cave, p. 185. Department of Education, Okinawa Prefectural Government. (in Japanese)

Hasegawa, Y., 1985. Note on Carnivore, Chiroptera and larger rat (Diplothrix) from Pinza-Abu Cave, Miyako Island, Okinawa, Japan. In: Pinza-Abu Cave, pp. 83-91. Department of Education, Okinawa Prefectural Government. (in Japanese)

— \& Nohara, T., 1978. The outline of Ishisukuyama vertebrate fossil assemblage, Ishigaki. In: Ishisukuyama, pp. 49-78. Department of Education, Okinawa Prefectural Government. (in Japanese)

\& Ono, K., 1979. Avian remains of Nagarabaru Nishi Midden. Reports on cultural assets of Ieson, 8: 255-268. (in Japanese)

— Otsuka, H. \& Nohara, T., 1973. Fossil vertebrates from the Miyako Island (studies of the palaeovertebrate fauna of Ryukyu Islands, Japan. Part I). Memoirs of the National Science Museum 6: 39-52, 2 pls. (in Japanese with English summary)

Hayashi, Y., 1985. Large wild boar from Pinza-Abu Cave, Miyako Island, Okinawa, Japan. In: Department of Education, Okinawa Prefectural Government, Pinza-Abu, pp. 75-78. (in Japanese)

Higuchi, H., 1979. Ecology of island bird. Scientific American Japanese Edition 9 (8): 74-88. (in Japanese)

Howard, R. \& Moore, A. 1994. A Complete Checklist of the Birds of the World, second edition, 630 pp. Academic Press.

Japan Weather Association, 1998. A Guide to the Climate of Okinawa. 121 pp. (in Japanese)

Kaneko, Y. \& Hasegawa, Y., 1995. Some fossil arvicolid rodents from the Pinza-Abu Cave, Miyako Island, the Ryukyu Islands, Japan. Bulletin of Biogeographical Society Japan 50 (1): 23-37.

Kawashima, Y., Ishimine, D. \& Oyama, S., 1985. Comparison of the teeth between the Ryukyu wild boar and the wild boar from Pinza-Abu Cave, Miyako Island, Okinawa, Japan. In: Pinza-Abu Cave, pp. 79-82. Department of Education, Okinawa Prefectural Government. (in Japanese)

Kuroda, N., 1925. A Contribution to the Knowledge of the Avifauna of the Riu Kiu Islands and the Vicinity. Tokyo.

, 1931. The Watase's line looking from the vertebrate distribution. Zoological magazine 43: 172-175. (in Japanese)

MacArthur, R. H. \& Wilson, E. O., 1967. The Theory of Island Biogeography, 203 pp. Princeton University press, Princeton, N. J.

Morioka, H., 1974. Avifauna of the Ryukyu Islands and its origin. Memoirs of the National Science Museum 7: 203-211.

Okinawa Yacho Kenkyu-kai, 1993. Wild Birds of Okinawa, 300 pp. Okinawa Shuppann, Okinawa.

Olson, S. L., 1973. Evolution of the rails of the South Atlantic islands (Aves: Rallidae). Smithsonian Contributions to Zoology 152: 1-53.

, 1990. The prehistoric impact of man on biogeographical patterns of insular birds. Atti dei Convegni Lincei 85: 45-51.

\& James H. F., 1982. Prodromus of the fossil avifauna of the Hawaiian Islands. Smithsonian Contributions to Zoology 365: 1-59.

\& -1984 . The role of Polynesians in the extinction of the avifauna of the Hawaiian Island. In: Martin, P. \& Klein, R. eds., Quaternary Extinctions, pp. 768-780. University of 
Arizona Press.

Ono, K. \& Hasegawa, Y., 1985. Preliminary Report on Late Pleistocene Avifauna from Pinza-Abu Cave, Miyako Island, Okinawa, Japan. In: Department of Education, Okinawa Prefectural Government, ed., Pinza-Abu, pp. 115-137. (in Japanese)

Oshiro, I. \& Nohara, T., 1977. The occurrence of fossil deer in the Ryukyus. Bulletin of the Okinawa Prefectural Museum no 3: 1-11. (in Japanese with English abstract)

Ripley, S. D., 1984. Rails of the World: A Monograph of the Family Rallidae, 31 pp. Smithsonian Institution Press, Washington, D. C.

Stattersfield, A. J., Crosby, M. J., Long, A. J. \& Wege D. C., 1998. Endemic Bird Areas of the World: Priorities for Biodiversity Conservation, $846 \mathrm{pp}$. Bird Life International, Cambridge.

Steadman, D. W., 1985. Fossil birds from Mangaia, southern Cook Islands. Bulletin of British Ornithological Club 105: 58-66.

, 1995. Extinction of birds on tropical Pacific islands. In: Steadman, D. W. \& Mead, J. I. eds., Late Quaternary Environments and Deep History: A Tribute to Paul S. Martin, pp. 33-49. The Mammoth Site of Hot Springs, south Dakota, Inc.

\& Olson, S. L., 1985. Bird remains from an archaeological site on Henderson Island, South Pacific: man caused extinctions on an "uninhabited" island. Proceeding of National Academy of Science, U.S.A. 82: 6191-6195.

Suzuki, H., 1982. Pleistocene man in Japan. Journal of Anthropological Society, Nippon, 90 (Suppl.), 11-16.

— \& Hanihara, K., eds., 1982. The Minatogawa Man: The Upper Pleistocene man from the island of Okinawa, 208 pp., 68 pls. The University Museum, The University of Tokyo, Bulletin, 19, Tokyo.

— \& Tanabe, G., 1982. Introduction. In: Suzuki, H. \& Hanihara, K., eds., The Minatogawa Man: The Upper Pleistocene Man from the Island of Okinawa, pp. 1-5. The University Museum, The University of Tokyo, Bulletin 19, Tokyo.

Tamagusuku, C. \& Nakamura, T., 1988. "Noguchigera (Sapheopipo noguchii): The Ecology and Habitat", 112 pp. Aki Shobou, Okinawa. (in Japanese)

Ujiié, H., 1994. Early Pleistocene birth of the Okinawa Trough and Ryukyu Islands Arc at the northwestern margin of the Pacific: evidence from Late Cenozoic planktonic foraminiferal zonation. Palaeogeography, Palaeoclimatology, Palaeoecology 108: 457-474.

UNESCO / IOC Western Pacific Subcommission, 1995. WESTPAC Paleogeographic Maps: The Last Glacial Maximum Paleogeographic Maps for the Western Pacific Region Text, 75 p. Marine Geology Laboratory, Tongji University, Shanghai.

Yamashina, Y., 1955. Distributional areas of the birds of the Ryukyu Islands. Bulletin of the Biogeographical Society of Japan 16-19 (Recent Conceptions of Japanese Fauna), pp. 371-375. (in Japanese with English Resume)

— \& Mano, T., 1981. A new species of rail from Okinawa Island. Journal of Yamashina Institute for Ornithology 13 (3): 147-152, 3 pls.

Zhen, B. \& Hasegawa, Y., 1985. Capreolus remains, its systematics and paleo-biological problem of Pinza-Abu Cave, Miyako Island, Okinawa, Japan. In: Department of Education, Okinawa Prefectural Government. ed., Pinza-Abu, pp. 33-73. (in Japanese) 


\section{松岡廣繁中・南部琉球列島の後期更新世古鳥類相，及びその現世列島鳥類相に対する} 意義

中部・南部琉球には後期更新世の裂罅・洞穴堆積物（おおむね最終氷期に形成されたもの）が発達してお り,これらの堆積物からはしばしば陸生脊椎動物群の優れた化石を豊富に産出する。沖縄島・伊江島・久 米島・宮古島・石垣島の各地から採集されたこれらの化石群を調べた結果, 11目17科に属する総計44種の 鳥類を認めた。本研究は化石記録を基に，現世鳥類相の形成過程についての考察を試みた。

\section{固有種の古動物地理}

中部琉球の沖縄諸島と奄美諸島は，動物地理学的に高い関連性をもった地域であることが，その森林のみ に共通して生息する固有種によって示される。ところが両諸島における鳥類の固有種は, その他の陸生脊 椎動物が中部琉球全域に分布するのに対して，島ごとにしか分布していない傾向がある。奄美大島のルリ カケス Garrulus lidthi とオオトラツグミZoothera major, 沖縄島のノグチゲラ Sapheopipo noguchii やヤン バルクイナ Gallirallus okinawae 等がその例である。なお沖縄島でのこうした固有動物の生息域は, 「ヤン バル」と呼ばれる北部の森林地帯に限られる。

これに対して，鳥類化石記録の研究から，後期更新世の沖縄島には全域的に現在のヤンバルのような森 林性の動物相が広がっていたと考えられ，また，中琉球における現生鳥類の “不思議” な固有種の分布パ ターンは, 「古固有」（周囲の個体群の消减）によって導かれたものであることが, 現在の分布域の外から 得られた化石記録によって判明した。現在の分布域の外から “固有種” の化石が産出するのである。例え ばノグチゲラの化石が沖縄島中部の石川市伊波城から発見された。またヤンバルクイナとアマミヤマシギ Scolopax mira の化石は沖縄島南部においても数多く発見され，しかもそれらには幼鳥のものが含まれる ので，当時はこの地方においても繁殖していたことがわかった。さらにアマミヤマシギ Scolopax mira は 宮古島からも化石が発見された。

この他に, 現在の生息地から “諸島レベル”で大きくはずれて, ルリカケスの化石が沖縄島南部の具志 頭村港川フィッシャーから化石が産出した。またオオトラツグミと考えられる大型ツグミの化石が港川と 宮古島ピンザ・アブ洞から産出した。こうした化石記録の研究から，かつては奄美諸島と沖縄諸島には森 林性鳥類相が連続しており，しかもこれは宮古島にまである程度広がっていたことが明らかとなった

一方, 宮古島は, その古動物相に独自の無飛翔性のツルとクイナを有しているなど, 列島の古脊椎動物 相において異質である。このことは後期更新世には，すでに琉球列島の他地域との地理的断絶が成立して いたことを強く示唆している。また，その旧北区系要素の強い動物化石相からは，宮古には沖縄卜ラフを またいで直接大陸と関連する “飛び石”的な“陸橋”ルートが存在したことが示唆される。

\section{区系動物地理学に生じる問題点}

現世の琉球列島の鳥類相を区系化するとき, 典型的な東洋区系の鳥類が八重山には留鳥で生息するため, 南部琉球を本列島における東洋区の北限とし, 南部琉球と中部琉球の間に境界「蜂須賀線」が認められて いる。この線が特徵的なのは，他の陸生脊椎動物が明らかに渡瀬線（トカラ海峡線）を境界とするのに対 し, 鳥類のみがより南にシフトした分布パターンを示すことである。琉球列島の現世鳥類相における，も う一つの “不思議” である。

これに対し今回の化石記録の研究により，「典型的な東洋区系の鳥」とされるオオクイナ Rallina eurizonoides の繁殖の証拠が蜂須賀線の北側, 沖縄島から得られた。またフィリッピン以南に生息する “アカチャゴイ” Nycticorax caledonicus がやはり沖縄から見つかった。さらにアマミヤマシギなどのよう に中部琉球を中心として宮古島（南部）まで分布していたものもいる。更新世の鳥類は蜂須賀線に関係な く, 列島の南部と中部を“行き来”しているのである。

化石の証拠に加え，分類学的にも，はじめは広く旧北区系とされた中部琉球の固有鳥類（山階, 1941, 1951）も，より個別的に見ればもっとも近縁なのは東洋区のメンバーと考えられる（森岡, 1974）ことから, 鳥類においても東洋区の北限は, 中部琉球の北（＝渡瀬線）にあると考えるのが適当であろう。蜂須賀線 は, “消えた分布域”に惑わされた，見せかけの境界線に過ぎないと考えられる。

琉球列島鳥類相の現状

中部琉球から南琉球にいたる島々の後期更新世脊椎動物化石群に認められた44種の鳥類の分布パターンは, 
現世鳥類相よりも“豊か”である。現世の有様は実は, すでに，あまりにも貧弱なものなのである。後期 更新世以後現在までに生じた個体群の消隇現象の最大の原因には, 貝塚期以降の人類活動の活発化が考え られる。

動物相は, 一度破壊されたら再び元の多様性を取り戻すことはない。奄美やヤンバルの森林はまさに最 後の砦なのだという認識を強く持って，その保全には格別の配慮を持ってあたるべきである。 